\title{
STUDI PEMBUATAN TEPUNG PISANG
}

\author{
Agus Nuroso, S.TP \\ Dosen Teknologi Pangan Faperta UNISI \\ ponyomr@yahoo.co.id
}

\begin{abstract}
ABSTRAK
Pengolahan tepung pisang bertujuan untuk menggali komoditas pangan (sumber karbohidrat lokal) untuk meningkatkan ketahanan pangan yang berasal dari pisang, mengetahui proses pembuatan tepung, mempromosikan pengolahan produk pangan yang berasal dari buah pisang menjadi tepung sehingga dapat memasuki dunia usaha, merupakan bahan alternatif tepung terigu, menambah pengetahuan dan memperkaya keilmuan tentang pengolahan. Buah pisang mempunyai kandungan karbohidrat $19,5 \%-21,5 \%$ dan dapat diolah menjadi produk setengah jadi yaitu tepung pisang. Karena buah tersebut tidak tahan lama maka ada suatu kebutuhan yang mendesak untuk menerapkan suatu teknologi yang tepat guna dan cara pengawetan, penyimpanan dan pengolahan buah. Teknologi dan cara pengolahan tersebut diperlukan untuk meningkatkan produksi bagi perusahaan kecil maupun menengah baik dalam kualitas maupun kuantitas sehingga mampu bersaing dengan pengusaha besar.
\end{abstract}

\section{PENDAHULUAN}

Buah merupakan salah satu komoditi bahan pangan yang cukup penting di Indonesia. Dari buah dapat diperoleh berbagai macam produk makanan yang murah dan bergizi untuk memenuhi kebutuhan masyarakat Indonesia. Pisang merupakan buah yang selalu ada sepanjang tahun dalam jumlah besar. Karena buah tersebut tidak tahan lama maka ada suatu kebutuhan yang mendesak untuk menerapkan suatu teknologi yang tepat guna dan cara pengawetan, penyimpanan dan pengolahan buah. Teknologi dan cara pengolahan tersebut diperlukan untuk meningkatkan produksi bagi perusahaan kecil maupun menengah baik dalam kualitas maupun kuantitas sehingga mampu bersaing dengan pengusaha besar. $\begin{array}{rrr}\text { Walaupun dalam } & \text { bentuk } \\ \text { masyarakat dapat kita jumpai }\end{array}$ tersedianya bahan makanan yang terbuat dari pisang, boleh dikatakan bahwa penggunaan pisang masih terbatas dalam bentuknya yang asli/ segar sebagai buahbuahan.

Dalam bentuk tersebut jika tertunda penggunaannya atau tidak semua dapat dikonsumsi akan menjadi lewat masak, rusak dan tidak dapat lagi dipergunakan sebagai bahan makanan. Ini banyak terjadi di daerah penghasil pisang sehingga terpaksa banyak pisang yang diserahkan dengan harga yang sangat murah.

Pengolahan buah secara terpadu dapat diterangkan sebagai suatu sistem 'input-output'. sebagai input adalah buah pisang dan output-nya adalah hasil 
olahan seperti tepung pisang, sale pisang, saus pisang, dan lain-lain. Dalam makalah ini yang menjadi output-nya adalah tepung pisang.

Proses perubahan input (buah pisang) menjadi output (tepung pisang) yang diinginkan meliputi pemanasan awal, penguapan, blanching, pencucian, pemotongan/pembelahan, pengeringan, penggilingan dan pengayaan.

\section{TINJAUAN PUSATAKA}

Pisang (Musa paradisiaca) adalah jenis buah-buahan yang terdapat hampir di seluruh Indonesia dan merupakan buah-buahan yang paling banyak diproduksi dan dikonsumsi masyarakat. Dari data statisik pada tahun 1981 diketahui bahwa produksi pisang mencapai 2.032.926 ton. Pisang yang dihasilkan tersebut banyak sekali jenisnya dan mempunyai kualitas yang berbeda-beda (Susanto dan Sameto, 1994).

Berdasarkan cara penggunaanya pisang dibagi menjadi atas dua golongan besar, yaitu banana dan plantain (Munadjim, 1983)

Banana merupakan golongan pisang yang dimakan dalam keadaan segar setelah buahnya masak (Musa paradisiaca var. sapientum dan Musa nan I,,), contohnya pisang ambon, pisang nangka, pisang angkleng, pisang raja sereh dan lain-lain. Sedangkan plantain merupakan golongan pisang yang dimakan setelah diolah lebih dahulu (Musa paradisiaca forma typica), misalnya pisang rotan, pisang kapas, pisang kepok dan lain-lain (Susanto dan Saneto, 1994)

Pisang banyak dipetik pada saat buahnya telah tua namun masih berwarna hijau, dengan kandungan total gula $0,1 \%$ dan pati $19,5-21,5 \%$. Pada proses pematangan buah terjadi kenaikan total gula karena sebagai besar pati diubah menjadi gula. Kombinasi kimai buah pisang bervariasi tergantung pada varietasnya, seperti terlihat pada tabel 1 .

Pisang termasuk buah klimakterik, maka setelah dipetik akan mengalami kemasakan lebih lanjut dan rusak jika tertunda penggunaannya. Oleh karena itu untuk memperoleh produk yang lebih panjang masa simpannya dan juga untuk meningkatkan nilai ekonomisnya, pisang sering diolah menejadi produk lain seperti sale, tepung, keripik, dodol, wine dan sebagainya (Susanto dan Saneto, 1994).

Pisang yang termasuk jenis plantain mempunyai kandungan pati yang tinggi dibanding jenis pisang buah segar, oleh karena itu pisang jenis inilah yang sering dipakai sebagai bahan pembuatan tepuang (Susanto dan Saneto, 1994).

Dari hasi penetilain Herdiman (1982), disebutkan bahwa pisang yang tingkat masaknya agak lanjut memberikan hasil tepung yang kurang baik karena pada tingkat kemasan tersebut kandungan gula reduksinya tinggi sehingga memungkinkan terjadinya reaksi pencoklatan sangat besar (Susanti dan Saneto, 1994) 
Tabel. 1. Kombinasi Kimia Beberapa Jenis Pisang Masak (tiap 100 g daging buah)

\begin{tabular}{|l|c|c|c|c|c|}
\hline \multirow{2}{*}{ Komponen } & \multicolumn{5}{|c|}{ Jenis Pisang } \\
\cline { 2 - 6 } & Ambon & Angleng & Raja & Sereh & Mas \\
\hline Air (g) & 72,0 & 80,3 & 65,8 & 67,0 & 64,2 \\
Kalori (kal) & 99 & 68 & 120 & 118 & 127 \\
Protein (g) & 1,2 & 1,3 & 1,2 & 1,2 & 1,4 \\
Lemak (g) & 0,2 & 0,2 & 0,2 & 0,2 & 0,2 \\
Karbohidrat (g) & 25,8 & 17,2 & 31,8 & 31,1 & 33,6 \\
Kalsium (mg) & 8 & 10 & 10 & 7 & 10 \\
Fosfor (mg) & 28 & 26 & 22 & 29 & 25 \\
Besi (mg) & 0,5 & 0,6 & 0,8 & 0,3 & 0,8 \\
Vitamin A (IU) & 146 & 76 & 950 & 112 & 79 \\
Vitamin B (mg) & 0,08 & 0,008 & 0,06 & - & 0,009 \\
Vitamin C (mg) & 3 & 6 & 10 & 4 & 2 \\
B.d.d. (\%) & 75 & 75 & 70 & 85 & 64,2 \\
\hline
\end{tabular}

Sumber : Anonymous (1979)

\section{BAHAN DASAR DAN ALAT}

\section{BAHAN}

Banyak faktor yang tercakup dalam masalah seleksi buah untuk pengolahan. Selain kualitas yang tinggi secara visual diinginkan bau, rasa, tekstur, warna dan nilai gizinya juga sangat penting. Kualitas ini hendaknya hanya berada sekecil mungkin sebelum dan sesudah pengolahan.

Faktor-faktor dasar yang mempengaruhi kualitas bahan dasar bermacam-macam yaitu tingkat kemasakan/ kematangan buah, penanganan sebelum dan sesudah panen.

Buah-buahan harus diseleksi secara hati-hati sebelum diolah. Buah harus pada tingkat kemasakan yang sesuai dan dalam kondisi yang sama seperti apabila dikonsumsi segar.

Tingkat kemasakan / kematangan dari bahan dasar yang akan diolah ditentukan oleh macam produk yang akan dibuat. Pisang yang diolah menjadi tepung, buahnya harus betul-betul masak, tetapi yang bebas dari suatu tanda kerusakan. Pengolahan harus mengambil pisang yang bebas dari kerusakan fisik dan serangan serangga. Untuk memperoleh hasil yang paling baik, bahan dasar harus diolah dalam waku 24 jam. Apabila terjadi kelembatan dalam pengolahan, buah harus disimpan dalam tempat yang dingin, dengan sirkulasi udara yang baik untuk mencegah pembusukan. Sirkulasi udara yang baik untuk mencegah pembusukan. Sirkulasi udara harus ada untuk menghilangkan panas yang disebabkan oleh buah. Buah-buah yang disimpan harus sering diamati untuk memisahkan buah yang rusak dan busuk dari buah yang baik.

Tingkat masak pisang dipilih tingkatan dimana telah ada satu atau dua pisang yang masak dalam satu tandan. Tingkat masak yang dipilih tersebut dengan pemikran bahwa kadar zat utama penyususn pisang yaitu pati telah mencapai maksimalnya (Yayasan Dian Desa, 1986)

Pisang yang digunakan adalah pisang yang matang tapi masih hijau kulitnya dengan berat $10 \mathrm{~kg}$. 


\section{SPESIFIKASI DAN}

\section{STANDARDISASI BAHAN DASAR}

1. Jenis : Pisang Gabu

2. Tingkat Kematangan : Matang, kulit masih hijau

3. Sifat Fisik : tidak ada memar, gangguan serangan atau busuk

4. Sifat khemis :

- Jumlah padat terlalu : $26-29^{0}$ Brix

- $\mathrm{Ph}: 5,3-5,7$

- Jumlah asam yang dapat dititrasi : 0,3-0,5\% (sebagai asam malat)

\section{PERALATAN}

1. Peranjang

2. Alat pengering tenaga matahari/ buatan

3. Alat Penutup plastik

4. Penggiling / penumbuk

5. Pisau tahan karat

6. Telenan / papan tipis

7. Mangkuk / panci

\section{PROSES}

\section{TAHAPAN PROSES}

\section{Pemanasan Awal}

Pembuatan tepung pisang dimulai dengan pemanasan awal $\left(90^{\circ} \mathrm{C}\right)$ selama 10-15 menit untuk menghindarkan pengaruh getah dan memudahkan pengupasan pisang mentah. (Hardiman, 1982)

Dengan perlakukan tersebut maka buah pisang menjadi layu, sehingga getahnya terdenaturasi dan mudah dikupas.

\section{Pengupasan}

Proses ini meliputi penghilangan kulit atau lapisan buah yang terluar.
Kulit dihilangkan karena mempengaruhi pembusukan makanan. Kulit juga kenampakkan produk tidak menarik. Pengupasan harus dikerjakan secara efisien untuk mencegah kehilangan bagian dari buah yang berguna. Pengupasan dengan tangan yang umum dikerjakan di pabrik-pabrik kecil. Pisau pengupas atau alat-alat lain juga sering digunakan dalam pengupasan. Pengupasan dengan tangan berjalan lambat, menjemput dan sering produk yang dihasilkan tidak standar.

\section{Blanching}

Blanching adalah suatu perlakuan dengnapanas dimana bahan makanan dicelupkan dalam air panas atau dikukus/ ditiup, kemudian diikuti dengan pendinginan atau penyemprotan dengan air dingin.

\section{Keuntungan :}

- Dalam proses ini gas-gas didesak keluar dari sel-sel tanaman sehingga meningkatkan kualitas hasil akhir.

- Membersihkan bahan dasar serta mengurangi terjadinya bakteri.

- Menghambat kerja enzim, memperlambat terjadinya perubahan warna menjadi coklat dan meningkatkan kualitas hasil menjadi lebih baik.

- Mempermudah pengupasan, pemotongan atau pengirisan

- Meningkatkan aroma dan warna dari beberapa produk sehingga aroma yang tidak disukai dapat hilang dan meningkatkan warna aslinya.

- Proses ini juga mempercepat proses pengolahan.

Blanching dengan air panas mungkin dilakukan secara bertahap atau kontinyu. Untuk pabrik-pabrik kecil umumnya dilakukan secara bertahap yaitu dengan menempatkan buah di 
dalam keranjang kasa dan mencelupkannya ke dalam air mendidih selama beberapa saat tergantung macamnya buah. Keranjang sebaiknya diisi hanya separo atau sepertiga saja agar memperoleh hasil yang baik. Lamanya waktu harus ditentukan secara tepat untuk memperoleh tekstur dan warna yang diinginkan. Blanching dalam air yang terlalu lama cenderung menyebabkan daging buah terlalu lunak. Mengurangi warna dan aroma serta menyebabkan berkurangnya nilai gizi.

\section{Pengirisan/Pemotongan}

Dalam mempersiapkan buah untuk diolah dilakukan pemotongan, pembelahan, penghilangan tangkai serta bagian-bagian lain yang tidak dapat dimakan. Langkah ini harus dikerjakan secepat mungkin untuk mencegah atau mengurangi perubahan warna. Untuk pengolahan jumlah kecil, langkah ini dikerjakan secara manual. Pemotongan dan pembelahan harus diamati secara hati-hati untuk memperoleh produk dengan kualitas yang baik. Kualitas yang baik akan memudahkan penetrasi panas. Kualitas yang baik ditandai dengan tidak adanya perubahan warna. Perubahan warna mungkin disebabkan beberapa alasan seperti proses yang terjadi dari buah itu sendiri. Alasan seperti proses oksidasi yang terjadi dari buah itu sendiri. Beberapa buah-buahan berupa warnanya karena penggunaan alat-alat dari besi atau tembaga. Pemasakan yang berlebihan dapat juga menyebabkan makanan menjadi terlalu coklat.

Oksidasi dari buah yang dikupas atau dipotong mungkin dicegah jika buah-buah tersebut segera diproses. Akan tetapi jika kelambatan tersebut tidak dapat dicegah, buah-buah yang sudah dikupas dapat dicelupkan dalam air atau larutan-larutan yang lain, tergantung pada macam produksinya. Larutan garam seperti halnya asam askorbat, asam sitrat, cuka atau cairan jeruk juga dapat digunakan. Lamanya waktu perendaman tergantung pada konsentrasi larutan dan macamnya buah. Makin lama perendaman menyebabkan buah menjadi asin, asam atau penerapan air. Maka apabila tidak terjadi keterlambatan pengolahan, perlakukan perendaman tidak perlu dilakukan.

Pengirisan ini dilakukan secara memanjang dengan ketebalan 0,5-1 cm.

\section{Pengeringan}

Buah pisang yang telah diiri harus segera kering, baik dengan pengeringan alami (dijemur) atau dengan pengeringan buatan. Pengeringan buatan baik yang modern maupun yang sederhana pempunyai keuntungan lebih dibanding dengan cara pengeringan alam yaitu temperatur dan aliran udara dapat diatur sehingga waktu pengeringan dapat diatur dengan lebih cepat, lebih bersih dan menghasilkan kualitas tepung yang lebih seragam. Dengan pengeringan buatan suhu diatur $70^{\circ} \mathrm{C}$ sampai mencapai kadar air sekira 8-10\%. Kepingan irisan pisang dianggap kering yaitu setelah menjadi keras tetapi rapuh. Jika cuaca jelek atau dikehendaki pengeringan yang lebih cepat, dapat dipergunakan api dapur yang diarahkan pada seng gelombang bahan atap dan diatasnya dapat diletakan tembir dengan kepingan pisang tadi.

Pengeringan juga dapat dilakukan di atas kawat kasa atau anyaman bambu yang diletakkan di atas meja yang bersih. Untuk memproleh hasil pengeringan yang seragam makan sirkulasi yang baik diantara irisan-irisan tersebut sangat penting. Tempat pengeringan harus bersih dan bebas dari debu dan lalat. 


\section{Penepungan/ Penggilingan}

Penepungna irisan pisang kering tersebut dapat dilakukan dengan gilingan ataupun ditumbuk yang kemudian diayak dengan ayakan yang berukuran 80 mesh.

\section{DIGRAM ALIR PROSES}

Diagram alir proses pembuatan tepung pisang (terlampir)

\section{SPESIFIKASI PROSES}

1. Waktu Pengringan : 24-26 jam

2. Temperatur pengeringan (maksimum)

Dalam : 750C

Luar $: 40^{\circ} \mathrm{C}$

\section{PENGAWASAN KUALITAS}

1. Sifat Fisik : Tidak ada memar, jamur dan gaungguan serangga

2. Sifat Khemis : Tidak ada

3. Spesifikasi : Buah tampak segar, matang penuh, utuh dan keras dan bebas dari memar, gangguan serangga atau busuk
4. Pengambilan contoh atau pengawasan : semua contoh dari kotak-kotak atau keranjang harus diamati yang warnanya kuning.

\section{HASIL OLAHAN}

\section{SPESIFIKASI PRODUK}

1. Sifat Fisik : warna kining kecoklatan sampai coklat muda

2. Sifat khimis :

$\begin{array}{ll}\text { Protein } & : 2-3 \% \\ \text { Pati } & : 70-75 \% \\ \text { pH } & : 6.0-6.8 \\ \text { Kadar air } & : 9-11 \%\end{array}$

3. Prosentasi hasil akhir : $9-12 \%$

4. Umur penyimpanan : 9-12 bulan

\section{PENGAWASAN KUALITAS}

1. Sifat Fisik : Warna kuning kecoklatan sampai coklat muda

2. Sifat Khemis :

$\mathrm{pH} \quad: \quad 6,0-6,9$

Protein (microjehldahl) : $2-3 \%$

Pati

: $70-75 \%$

\section{KOMPOSISI KIMIA TEPUNG PISANG}

Tabel 2. Komposisi Kimia Tepung Pisang Dibanding dengan Besar dan Kentang (tiap $1000 \mathrm{~g}$ bahan)

\begin{tabular}{|l|c|c|c|}
\hline \multirow{2}{*}{ Komponen } & \multicolumn{3}{c|}{ Tepung } \\
\cline { 2 - 4 } & Pisang & Beras & kentang \\
\hline Air (g) & 3 & 12 & 78 \\
Kalori (kal) & 340 & 363 & 82 \\
Protein (g) & 4,4 & 6,7 & 2,0 \\
Lemak (g) & 0,8 & 0,4 & 0,1 \\
Karbohidrat (g) & 88,6 & 80,4 & 19 \\
Serat Kasar (g) & 2,0 & 0,3 & 0,4 \\
Abu (g) & 3,2 & 0,5 & 1,1 \\
Vitamin- & 76,92 & 0,17 & 16,23 \\
vitamin (mg) & \multicolumn{3}{|c|}{ Sumber : Dahjawak(1981) } \\
\hline
\end{tabular}




\section{PENGEPAKAN DAN PENYIMPANAN}

Apabila tepung pisang tidak akan langsung digunakan atau supaya tepung pisang dapat tahan lama, maka tepung pisang tersebut hendaknya dimasukkan/ dikemas ke dalam kantong plastik yang kemudian disimpan pada temperatur kamar.

\section{KEGUNAAN / POTENSI}

Pengusahaan makanan banyak
memakai tepung pisang dalam pembuatan roti, biskuit, gula-gula, tepung biji-bijian dan saus karena tepung tersebut dapat menggantikan sebagai tepung gandum dan hasil yang diperoleh bagus kualitasnya.

Tepung pisang pengandung gluten sehingga perlu mencampurkannya dengan tepung gandum agar bisa renyah dan mengembang.jumlah tepung gandum yang digantikan sebanyak $25 \%$. Tepung pisang dapat digunakan dalam pembuatan makareni, spageti dan pengganti beras : juga untuk campuran tepung biji-bijian atau tepung ketela dan pada pembuatan perekat.
Juga dapat sebagai bahan dasar pembuatan saus pisang atau sebagai bahan campuran yang pokok dalam pembuatan saus yang lain.

\section{KESIMPULAN}

Tepung pisang adalah produk yang berwarna kuning kecoklatan sampai coklat muda terbuat dar pisang yang sudang tua tepi belum masak. Daging buah dapat diubah sebanyak $40 \%$ sehingga tepung tersebut masih berbau dan beraroma pisang. Tepung diperoleh dengan jalan memanaskan pisang yang tua namun masih hijau kulitnya, dikupas, diblanching, dicuci, diiris tipus-tipus kemudian dikeringkan di atas nampan atau nampan sehingga kering betul, dan terakhir digiling atau ditumbuk. Tepung pisang tidak mengandung gluten, oleh karena itu perlu dicampur dengan tepung lain agar bisa reneyah dan mengembang. Tepung pisang dapat mengganti tepung gandum sebanyak $25 \%$ dalam pembuatan roti, kue-kue dan lain-lain. Danjuga dapat dipakai sebagai bahan dasar pembuatan saus pisang. 


\section{LAMPIRAN}

Diagram Alir Proses Pembuatan Tepung Pisang

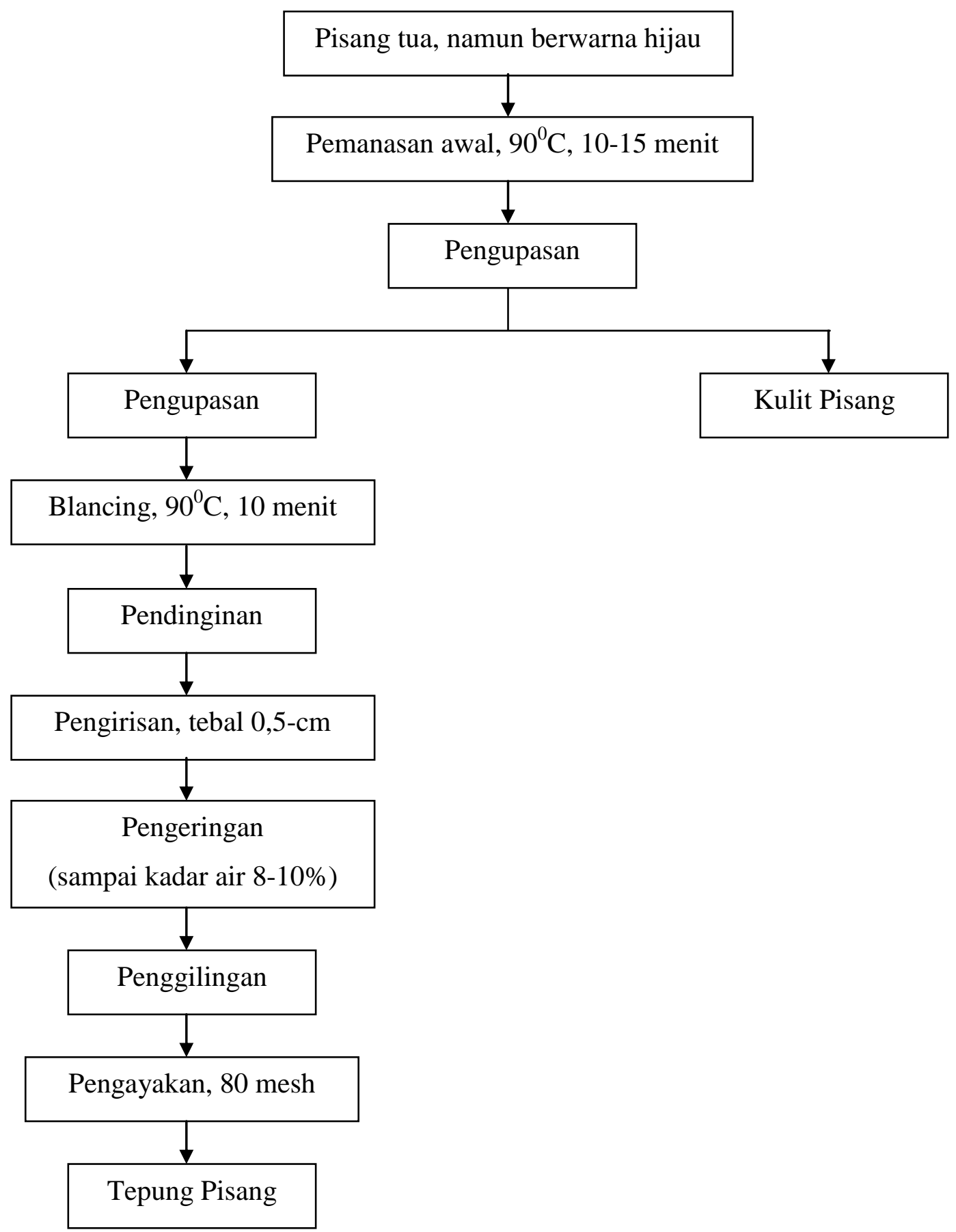




\section{DAFTAR PUSTAKA}

Anonymous. 199. Daftar Komposisi

Bahan Makanan. Direktorat Gizi

Departemen Kesehatan RI.

Bharata. Jakarta

Dadhawakt, J. 1981. Pisang dan

Langkah Menuju Kemakmuran.

Lembaga Studi dan

Pengembangan Bahan Pangan

baru. Swadiri-Indonesia. Jakarta
Hardiman. 1982. Tepung Pisang. Gadjah Mada University Press. Yogyakarta

Susanto, Tri dan Saneto, Budi. 1994. Teknologi Pengolahan Hasil Pertanian. Cetakan I. Bina Ilmu. Surabaya.

Yayasan Dian Desa dan Batek Center. 1986. Proses Pengolahan Pisang dan Nanas Secara Terpadu. USAID COIME dan Techninet Asia.

Yogyakarta. 